\title{
Can enemy release explain the invasion success of the diploid Leucanthemum vulgare in North America?
}

\author{
Sonja Stutz $\cdot$ Kateřina Štajerová $\cdot$ Hariet L. Hinz $\cdot$ \\ Heinz Müller-Schärer · Urs Schaffner
}

Received: 4 August 2015/Accepted: 25 April 2016/Published online: 29 April 2016

(C) Springer International Publishing Switzerland 2016

\begin{abstract}
Enemy release is a commonly accepted mechanism to explain plant invasions. Both the diploid Leucanthemum vulgare and the morphologically very similar tetraploid Leucanthemum ircutianum have been introduced into North America. To verify which species is more prevalent in North America we sampled 98 Leucanthemum populations and determined their ploidy level. Although polyploidy has repeatedly been proposed to be
\end{abstract}

Electronic supplementary material The online version of this article (doi:10.1007/s10530-016-1152-z) contains supplementary material, which is available to authorized users.

S. Stutz $(\varangle) \cdot$ H. L. Hinz · U. Schaffner

CABI, Rue des Grillons 1, 2800 Delémont, Switzerland

e-mail: s.stutz@cabi.org

S. Stutz · H. Müller-Schärer

Department of Biology, Ecology and Evolution,

University of Fribourg, Chemin du Musée 10,

1700 Fribourg, Switzerland

\section{K. Štajerová}

Department of Invasion Ecology, Institute of Botany,

The Czech Academy of Sciences, 25243 Průhonice,

Czech Republic

K. Štajerová

Department of Ecology, Faculty of Science,

Charles University in Prague, Viničná 7, 12844 Prague,

Czech Republic associated with increased invasiveness in plants, only two of the populations surveyed in North America were the tetraploid L. ircutianum. We tested the enemy release hypothesis by first comparing 20 populations of $L$. vulgare and 27 populations of $L$. ircutianum in their native range in Europe, and then comparing the European L. vulgare populations with 31 L. vulgare populations sampled in North America. Characteristics of the site and associated vegetation, plant performance and invertebrate herbivory were recorded. In Europe, plant height and density of the two species were similar but $L$. vulgare produced more flower heads than L. ircutianum. Leucanthemum vulgare in North America was $17 \%$ taller, produced twice as many flower heads and grew much denser compared to L. vulgare in Europe. Attack rates by root- and leaf-feeding herbivores on L. vulgare in Europe (34 and $75 \%$ ) was comparable to that on L. ircutianum ( 26 and $71 \%$ ) but higher than that on L. vulgare in North America (10 and $3 \%$ ). However, herbivore load and leaf damage were low in Europe. Cover and height of the co-occurring vegetation was higher in L. vulgare populations in the native than in the introduced range, suggesting that a shift in plant competition may more easily explain the invasion success of $L$. vulgare than escape from herbivory.

Keywords Biogeography · Enemy release · Herbivores · Oxeye daisy · Plant invasions . Polyploidy 


\section{Introduction}

Comparative studies assessing performance of invasive alien plant species under field conditions revealed that they often perform better in their introduced than in their native ranges (Hinz and Schwarzlaender 2004; Parker et al. 2013). One of the most prominent hypotheses explaining their increased size and abundance in their introduced range is the enemy release hypothesis (Keane and Crawley 2002; Colautti et al. 2004). It is based on the assumptions that populations in the native range are regulated by their associated natural enemies and that, when introduced into new ranges, they escape from their specialist natural enemies. The decreased regulation by natural enemies in the introduced range is expected to result in an increase in plant growth, reproduction and abundance. However, plants in the introduced range may not completely escape from herbivores since specialist herbivores might have been co-introduced with them or specialists of closely related native congeners might switch to attack the introduced plant species (Keane and Crawley 2002). In addition, resident generalist herbivores may start exploiting the new food source (Maron and Vilà 2001). Previous studies have found that invasive plants generally experience reduced attack by herbivores or are attacked by fewer species of herbivores in the invaded compared to the native range (Colautti et al. 2004; Liu and Stiling 2006; Heger and Jeschke 2014).

Herbivores do not always have negative effects on species performance in their native range (Prior et al. 2015) and only few studies tested if the observed differences in damage between ranges have an impact in regulating plant populations (DeWalt et al. 2004; Williams et al. 2010; Roy et al. 2011). Theoretically, exotic plants that experience high herbivore attack in their native range are more likely to escape top-down regulation and become invasive in the introduced range than plant species that experience only low levels of herbivory in their native range. Beside an escape from natural enemies, invasive plants may also profit from a release from competition with neighbouring plants (Crawley 1986; Callaway et al. 2011) or from more favourable climatic conditions in the introduced ranges (Erfmeier and Bruelheide 2004; Cripps et al. 2010). To gather support for any of these mechanisms that might explain invasion success, it is necessary to apply a biogeographic approach by comparing invasive plants in their native and introduced ranges (Hierro et al. 2005).

Polyploidy has been proposed to be associated with invasiveness in plants (Müller-Schärer et al. 2004; Pandit et al. 2011, 2014; te Beest et al. 2012; Hahn et al. 2012a), through, for instance, increased phenotypic variation, fixed heterosis or reduced inbreeding depression, which may pre-adapt polyploids to become invasive or increase their ability to adapt to novel conditions post-introduction (Soltis and Soltis 2000; Comai 2005; te Beest et al. 2012, Hahn et al. 2012b). Polyploidy has been found to be overrepresented in invasive plants (Pandit et al. 2011, 2014) and in various taxa with more than one ploidy level in the native range, only polyploids have become invasive (e.g. Lafuma et al. 2003; Kubátová et al. 2008; Schlaepfer et al. 2008; Treier et al. 2009). Furthermore, polyploids are expected to exhibit increased concentrations of secondary metabolites compared to their diploid progenitors and may therefore experience greater levels of herbivore resistance (Levin 1983; Dhawan and Lavania 1996).

In this study we surveyed two closely related plant species, the diploid Leucanthemum vulgare (Vaill.) Lam. (Asteraceae) and the tetraploid Leucanthemum ircutianum DC in their native (Europe) and introduced (North America) ranges. Both species are very similar in their morphology and have often been treated as a species complex (in the following referred to as " $L$. vulgare s.l.") together with various other species (Heywood 1976; Hegi 1987; Greuter (2006). Oberprieler et al. (2011) described L. ircutianum as an allopolyploid with $L$. vulgare and possibly $L$. virgatum (Desr.) Clos as parental species. In their native range (Europe and western Asia), L. vulgare and $L$. ircutianum are both widely distributed, but $L$. ircutianum is reported to be more common than L. vulgare (Zelený 1982; Vogt 1991; Zelený 2004; Oberprieler et al. 2011). Leucanthemum vulgare s.l. has been introduced to North America as ornamental and seed contaminant and now invades pastures, meadows, roadside areas and forest openings (Olson and Wallander 1999; Clements et al. 2004). In North America, it was reported to be naturalized in Québec and in the north-eastern USA by the eighteenth century (Fernald 1903; Lavoie et al. 2012). Nowadays, it is common in the north-eastern and north-western states of the USA and in the south-eastern and south-western provinces 
of Canada (Olson and Wallander 1999; Clements et al. 2004). Beside North America, L. vulgare s.l. has also been introduced to many other parts of the world, including South America, Australia, New Zealand and India (Holm et al. 1979; Khuroo et al. 2010). To suppress $L$. vulgare s.l. or to stimulate the growth of competing vegetation, application of herbicides or fertilizer, respectively can be effective (Olson and Wallander 1999; Clements et al. 2004); however, this is not feasible over large areas. A biological control programme for $L$. vulgare s.l. was therefore initiated in 2008, but no agents have been released so far (McClay et al. 2013). Morphological surveys and chromosome counts from the eastern part of North America indicate that in this area $L$. vulgare might be more common than L. ircutianum (Fernald 1903; Mulligan 1958). However, western parts of North America have not been surveyed yet and the relative abundance of the two species across their introduced range remains unclear.

The first objective of our study was to assess the relative abundance of the diploid $L$. vulgare and the tetraploid L. ircutianum in North America by using flow cytometry to identify the ploidy level of 98 sampled populations. In our second objective, we tried to find indications whether enemy release may help explain the invasion success of $L$. vulgare in North America, which was found to be far more common than the tetraploid L. ircutianum. To assess whether herbivore attack is higher on $L$. vulgare than on $L$. ircutianum in their native range, and whether $L$. vulgare might therefore profit more from enemy release in the introduced range, we compared the herbivore communities and attack rates between $L$. vulgare and L. ircutianum in two regions in Europe surveying a total of 47 populations. We also recorded plant performance and site characteristics to assess whether they could explain potential differences in herbivory. We then compared the performance and herbivore attack of $L$. vulgare between the native and introduced range, by surveying $31 \mathrm{~L}$. vulgare populations in North America. We hypothesized that (1) in their native European range, L. vulgare has higher herbivore attack rates than L. ircutianum, (2) herbivore attack rates are reduced in the invaded compared to the native range, and (3) L. vulgare populations in North America are denser and plants larger than in the native range.

\section{Materials and methods}

\section{Ploidy screening}

To investigate the relative abundance of $L$. vulgare and L. ircutianum in their introduced range, a total of 98 populations were sampled from 2008 to 2013. Thirty-one of the populations were sampled during our own field surveys (Online Resource 1) and 67 populations were sampled by colleagues (Online Resource 2). Because L. vulgare and L. ircutianum are similar in morphology, seeds were separately collected from one to ten plants with a minimum distance of $2 \mathrm{~m}$ and used for subsequent ploidy level determination using flow cytometry (for number of plants analysed, see Online Resource 1 and Online Resource 2). Since in the native range mixed-ploidy populations are rare (Zelený 1982), we analysed two bulk samples per population each containing two seeds from up to five plants but we separately analysed plants with atypical morphology. Previous analyses revealed that analyses of bulk samples with two seeds from five plants still allowed us to reliably detect mixed ploidy levels within a sample. The seeds were transferred into small Petri dishes together with a few drops of general-purpose buffer and chopped with a sharp razor blade following the protocol of Loureiro et al. (2007). After this, $950 \mu \mathrm{l}$ of the buffer were added and the mix was incubated for approximately $1 \mathrm{~min}$ and then filtered through a $30-\mu \mathrm{m}$ nylon filter. Afterwards, $30 \mu \mathrm{l}$ of a staining solution composed of RNAse (1\%) and propidium iodide (1\%) was added. The extracted and stained nuclei were analysed with a Partec Cyflow SL cytometer equipped with a green laser functioning at $532 \mathrm{~nm}$. Seeds from a $L$. vulgare plant whose ploidy level was known from previous analyses were used to adjust the laser.

\section{Field surveys}

\section{Sampling design}

To compare plant performance, herbivore communities, herbivore attack rates and site characteristics, a total of 78 L. vulgare and L. ircutianum populations were surveyed in Europe and North America in 2013 (Fig. 1, Online Resource 1). In Europe, 24 populations were sampled across the Czech Republic and adjacent 
2080

S. Stutz et al.
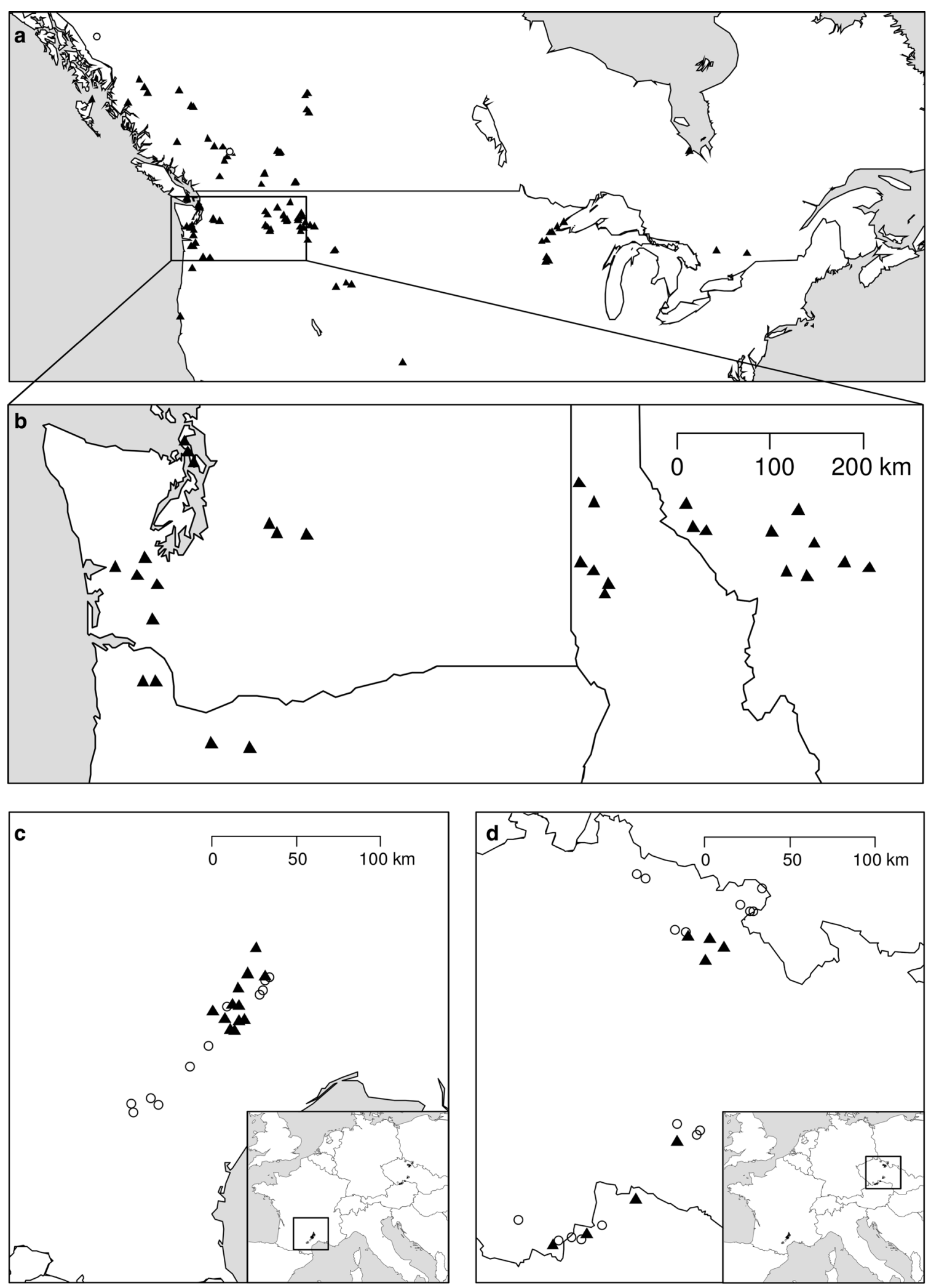

Springer 
4Fig. 1 Locations of populations of L. vulgare (triangles) and $L$. ircutianum (circles) surveyed in the invaded (North America) and native (Europe) range. a Populations surveyed for ploidy level in North America. b, c, d Populations surveyed for ploidy level, herbivores, plant performance and site characteristics in Washington, Oregon, Idaho and Montana (b), in France (c) and in the Czech Republic and adjacent parts of Austria (d)

parts of northern Austria and 23 populations in southern France. These two regions were selected because herbarium records and previous surveys revealed that both L. vulgare and L. ircutianum occur there. In North America, 15 sites were sampled in western Washington and north-western Oregon and 16 sites in northern Idaho and north-western Montana. The minimum distance between surveyed populations was $2 \mathrm{~km}$ in Europe and $12 \mathrm{~km}$ in North America. With the exception of two North American sites, only populations which had not been mown or grazed during the previous months were included in the surveys. All surveys were conducted towards the end of the flowering period of the plants when the shoots had reached their maximum height. Populations in Europe were sampled from 12 to 18 June (Czech Republic and Austria) and from 24 to 29 June (southern France) and populations in North America were sampled from 25 July to 4 August.

\section{Geographic location and climatic data}

To compare the climatic conditions of the native and invaded range, climatic data were obtained from the National Climatic Data Center (http://www.ncdc. noaa.gov/). Weather stations that were closest to the 78 sampled populations were chosen and mean annual temperature, mean minimum temperature of the coldest month, mean maximum temperature of the warmest month, and mean annual precipitation were calculated for the years 1998-2012. Coordinates and altitude for each sampled population were recorded in the field using a GPS.

\section{Plant performance}

To estimate population density, five $1 \mathrm{~m} \times 1 \mathrm{~m}$ quadrats were placed every $7 \mathrm{~m}$ along a transect and all Leucanthemum shoots as well as all rosettes were counted in the quadrats. From each population 20 flowering plants were randomly chosen along the transect with a maximum distance of $1 \mathrm{~m}$ from the transect and a minimum distance of $2 \mathrm{~m}$ between the plants. Of these, we measured the length of the longest shoot and counted the number of shoots and flower heads per plant. The number of flower heads per shoot was then used to compute the density of flower heads per square meter. Whenever available, seeds were collected from each of the selected plants for subsequent ploidy level determination (see above).

\section{Herbivory}

Damage by leaf herbivores was estimated for each collected plant using the following scoring system (after Lewis et al. 2006): $0=$ no damage; $1=$ minimal damage with no more than approximately $5 \%$ of any leaf damaged; $2=$ minimal damage plus some leaves with $5-10 \%$ damage; $3=10-50 \%$ damage on multiple leaves, but fewer than half of all leaves affected; $4=$ at least half of all leaves with 10-50\% damage and multiple leaves with more than $50 \%$ damage. The roots of the selected plants were dissected and all root-attacking herbivores were recorded. To estimate the proportion of plants with attack by root herbivores we also recorded whether the roots showed mining damage from previous attack. In addition, all flower heads were dissected and attack by the most abundant herbivores was recorded. Dissections were done directly in the field for North American populations, whereas plants from European populations were dissected using a microscope in the laboratory.

\section{Site characteristics}

All field sites were assigned to one of the following habitat types: roadside, grassland, forest or ruderal (defined as sites with soil disturbance, but not grazed or mown, e.g. waste areas or landfills). It was estimated whether the site was mown or grazed in the preceding year (by looking for dried flowering stalks dating from the preceding year and for livestock manure or by consulting the farmers), and we recorded whether there were any signs of soil disturbance. In addition, the following vegetation parameters were determined within each of the five $1 \mathrm{~m} \times 1 \mathrm{~m}$ quadrats placed along the transect: (1) visual estimates of vegetation cover (excluding Leucanthemum), (2) species richness of forbs and grasses and (3) average 
vegetation height in the centre of each of the five quadrats, estimated by placing a hand lightly on the vegetation at the level reached by about $80 \%$ of the vegetation ("direct measurement method" after Stewart et al. 2001). Also, since L. vulgare has been reported to prefer calcareous-rich sites (Oberprieler et al. 2011), two soil samples were collected from each sampled population at a depth of 5-7 cm and the $\mathrm{pH}$ was recorded in the field using a soil $\mathrm{pH}$ tester (Luster Leaf Products, Inc. Woodstock, Illinois).

Statistical analyses

\section{Climate, altitude and latitude}

To investigate whether mean annual temperature, average minimum temperature of the coldest month, average maximum temperatures of the warmest month, mean annual precipitation, altitude and latitude of the sampled $L$. vulgare populations differed between the two ranges $t$ tests were performed.

\section{Plant performance}

Generalized linear mixed models and linear mixed models with plant population nested in four geographic regions (Czech Republic and Austria, France, Washington and Oregon, Idaho and Montana) as random factor were performed to test whether the number of shoots per plant, the number of flower heads per plant, the number of flower heads per shoot and the length of the longest shoot differed between native $L$. vulgare and L. ircutianum plants and between native and introduced $L$. vulgare plants. To analyse whether the number of rosettes, shoots and flower heads per square meter differed between plant species and range, we carried out linear mixed models on population means with geographic region as random factor. The number of flower heads per shoot, and the number of Leucanthemum rosettes, shoots and flower heads per square meter were $\log _{\mathrm{e}}(\mathrm{X})$ transformed to meet underlying assumptions of linear mixed models. To explore whether the observed differences in the performance of $L$. vulgare between ranges are still significant when controlling for climatic differences, we also included mean annual temperature, average maximum temperatures of the warmest month, mean annual precipitation, altitude and latitude as fixed effects in the models comparing $L$. vulgare in the native and introduced range. The average minimum temperature of the coldest month was highly correlated with the mean annual temperature $(r=0.92)$ and therefore not included in the models. The best-fitted models were selected based on likelihood ratio tests.

\section{Site characteristics}

ANOVAs were performed to determine whether species richness and vegetation height differed between native $L$. vulgare and $L$. ircutianum populations and between native and introduced $L$. vulgare populations. Because the assumptions for ANOVA were not met for data on soil $\mathrm{pH}$ and vegetation cover, non-parametric Kruskal-Wallis tests were carried out instead. $\chi^{2}$ tests were performed to test for differences in the proportions of populations that were mown or grazed and the proportions of populations with soil disturbance.

Pearson's product moment correlation tests were used to explore whether the performance of $L$. vulgare (shoot density, plant height, number of flower heads per plant) is correlated with differences in plant competition (vegetation cover, vegetation height and number of plant species). The data were analysed separately for native and introduced $L$. vulgare populations. Two sites in North America that were grazed by cattle or horses and where vegetation parameters could not be accurately estimated were excluded from these analyses.

\section{Herbivory}

$\chi^{2}$ tests were performed to compare the frequency distribution of leaf damage scores of native $L$. vulgare and L. ircutianum populations and of native and introduced $L$. vulgare populations. Generalized linear mixed models with plant population nested within geographic region as random effect and continent as fixed effect were used to compare the proportion of native and introduced $L$. vulgare plants attacked by root herbivores. To analyse if the proportion of plants attacked by root herbivores (total attack and attack by the three most abundant root herbivores) and the total number of root-attacking larvae and pupae found per plant (herbivore load) differs between L. vulgare and L. ircutianum in Europe and whether plant performance and site characteristics could explain potential differences in herbivory we used generalized linear 
mixed models. Plant population nested within geographic region was included as random effect and Leucanthemum species, the number of shoots per plant, shoot density and vegetation height were included as fixed effects. For the analyses of herbivore load, plants in which only mining but no larvae or pupae were found were assigned to have a herbivore load of one. The best-fitted models were selected using likelihood ratio tests. To assess the significance of each parameter included in the best-fitted model, models with and without the respective parameter were compared.

All analyses were performed with the software $\mathrm{R}$ version 3.1.2 ( $\mathrm{R}$ Core Team 2014). Linear mixed models (for normally distributed data) were done using the function lme in the nlme package (Pinheiro et al. 2014) and generalized linear mixed models (for binomial and count data) were done using the function glmer in the lme4 package (Bates et al. 2014). Binomial distribution was used on proportions, Poisson distribution was used on counts and Gaussian distribution was used for normally distributed dependent variables. Separate analyses were conducted to compare European L. vulgare with $L$. ircutianum and European with North American L. vulgare populations.

\section{Results}

Ploidy level determination

Flow cytometric analyses revealed that all except for two populations from the introduced range were diploid and thus L. vulgare (Fig. 1a, b, Online Resource 1 and 2). Eight of the 24 sites sampled in central Europe (Czech Republic and Austria) and 12 of the 23 sites sampled in western Europe (southern France) were L. vulgare, the remaining European populations were L. ircutianum (Fig. 1c, d, Online Resource 1). In all of the populations only one ploidy level was detected.

\section{Climate, altitude and latitude}

For the sampled sites, mean annual temperature was higher in Europe than in North America $\left(9.9 \pm 0.3{ }^{\circ} \mathrm{C}\right.$ vs. $8.4 \pm 0.5^{\circ} \mathrm{C}, t=3.1, P=0.003$ ), whereas average maximum temperature of the warmest month was higher in North America $\left(27.5 \pm 0.5^{\circ} \mathrm{C}\right.$ vs. $26.1 \pm$ $0.2{ }^{\circ} \mathrm{C}, t=2.7, P=0.009$ ) (Online Resource 1). All other climatic variables as well as altitude and latitude were similar between both ranges $(P>0.05)$.

Plant performance

In Europe, L. vulgare had on average $60 \%$ more shoots and flower heads than L. ircutianum, whereas plant height, rosette-, shoot-, and flower head densities were similar between the two species (Table 1, Online Resource 3: Table S1). In the introduced range, $L$. vulgare were significantly taller, had a similar number of shoots per plant but produced twice as many flower heads compared to their native counterparts. Rosette density of $L$. vulgare was ten times higher, shoot density three times higher and flower head density five times higher in populations from the introduced compared to the native range (Table 1). Differences in plant performance and density of $L$. vulgare populations between the introduced and native ranges remained highly significant when climatic variables were included as covariates in the analyses (Online Resource 3: Table S2).

Habitat and site characteristics

In Europe, all measured site characteristics were similar for populations of L. vulgare and L. ircutianum (Table 2, Online Resource 3: Table S3, Online Resource 4). Soil $\mathrm{pH}$ was similar between $L$. vulgare sites in North America and Europe while vegetation cover, vegetation height, and forb and grass species richness were significantly lower in North America (Online Resource 4: Table S4). In both ranges, the majority of populations were sampled from grasslands (Online Resource 4). The proportion of populations with soil disturbance and the proportion of populations which were grazed in the year preceding our survey were similar between European and North American L. vulgare populations $(P>0.1$, Online Resource 4$)$ but North American populations were less often mown than European $L$. vulgare populations (34.8 vs. $\left.75.0 \%, \chi^{2}=10.0, P=0.002\right)$.

The number of flower heads per plant and the density of L. vulgare shoots were negatively associated with vegetation cover (number of flower heads: $r^{2}=0.18, P=0.02$; density: $\left.r^{2}=0.4, P<0.001\right)$ in the introduced but not in the native range. They were 
Table 1 Mean values $( \pm \mathrm{SE})$ of plant and population traits of $L$. vulgare and L. ircutianum populations in the native (Europe, EU) and invaded (North America, NA, only L. vulgare) range

\begin{tabular}{lccccc}
\hline & L. ircutianum $(\mathrm{EU})$ & vs. & L. vulgare (EU) & vs. & L. vulgare (NA) \\
\hline Maximum shoot height $(\mathrm{cm})$ & $49.1 \pm 1.6$ & n.s. & $45.5 \pm 1.6$ & $*$ & $54.5 \pm 1.6$ \\
Number of shoots & $1.6 \pm 0.1$ & $* * *$ & $2.6 \pm 0.4$ & n.s. & $3.0 \pm 0.3$ \\
Number of flower heads & $1.9 \pm 0.2$ & $* *$ & $3.3 \pm 0.5$ & $* * *$ & $6.2 \pm 0.9$ \\
Number of flower heads/shoot & $1.2 \pm 0.0$ & n.s. & $1.3 \pm 0.1$ & $*$ & $2.1 \pm 0.1$ \\
Number of shoots $/ \mathrm{m}^{2}$ & $16.6 \pm 4.8$ & n.s. & $11.2 \pm 1.9$ & $*$ & $33.2 \pm 5.0$ \\
Number of rosettes $/ \mathrm{m}^{2}$ & $6.9 \pm 2.3$ & n.s. & $3.3 \pm 0.9$ & $*$ & $32.1 \pm 5.4$ \\
Number of flower heads $/ \mathrm{m}^{2}$ & $19.5 \pm 5.1$ & n.s. & $15.1 \pm 2.9$ & $*$ & $74.7 \pm 14.0$ \\
\hline
\end{tabular}

* $P<0.05$, ** $P<0.01$, *** $P<0.001$, mixed effect models; separate analyses were performed to compare European $L$. vulgare and L. ircutianum populations and European and North American L. vulgare populations, respectively

Table 2 Mean values ( $\pm \mathrm{SE}$ ) of site characteristics of $L$. vulgare and L. ircutianum populations in the native (Europe, EU) and invaded (North America, NA, only L. vulgare) range

\begin{tabular}{lccccc}
\hline & L. ircutianum $(\mathrm{EU})$ & vs. & L. vulgare (EU) & vs. & L. vulgare (NA) \\
\hline${\text { Vegetation cover }(\%)^{\mathrm{a}}}^{\mathrm{a}}$ & $92.9 \pm 1.5$ & n.s. & $92.3 \pm 2.0$ & $*$ & $75.9 \pm 3.1$ \\
${\text { Mean vegetation height }(\mathrm{cm})^{\mathrm{a}}}^{\mathrm{a}}$ & $37.7 \pm 2.8$ & n.s. & $38.3 \pm 3.9$ & $* * *$ & $22.1 \pm 1.8$ \\
Number of forb species $^{\mathrm{a}}$ & $10.4 \pm 0.3$ & n.s. & $9.8 \pm 0.4$ & $* * *$ & $4.1 \pm 0.3$ \\
Number of grass species $_{\text {Total number of species }}{ }^{\mathrm{a}}$ & $2.5 \pm 0.1$ & n.s. & $2.4 \pm 0.1$ & $* * *$ & $1.7 \pm 0.1$ \\
Soil pH & $12.9 \pm 0.3$ & n.s. & $12.2 \pm 0.4$ & $* * *$ & $5.7 \pm 0.3$ \\
\hline
\end{tabular}

a Of vegetation other than Leucanthemum

* $P<0.05$; *** $P<0.001$, Kruskall-Wallis tests (for soil $\mathrm{pH}$ and vegetation cover) or ANOVAs (for all other variables). Separate analyses were performed to compare European L. vulgare and L. ircutianum populations and European and North American $L$. vulgare populations, respectively

not correlated with the number of co-occurring plant species $(P>0.05)$. The average height of $L$. vulgare was positively correlated with vegetation height in the native $\left(r^{2}=0.30, \quad P=0.01\right)$ and introduced ( $\left.r^{2}=0.31, P=0.002\right)$ ranges but was not associated with vegetation cover or the number of co-occurring plant species.

Herbivores

\section{Comparison of European L. vulgare and L. ircutianum}

In Europe, the frequency distribution of leaf damage scores was similar between $L$. vulgare and $L$. ircutianum $\left(\chi^{2}=0.9, P=0.9\right)$ and the majority of plants had low leaf damage scores of 1 or 2 (Fig. 2a). The best-fitted models to explain the proportion of plants attacked by root herbivores (Fig. 2b) and the number of root herbivores found per plant (herbivore load) revealed a positive correlation with the number of shoots per plant for both response variables $(z=4.64$, $P<0.001$ and $z=9.5, P<0.001)$ but did not include Leucanthemum species, shoot density or vegetation height as explanatory variables (Online Resource 3: Table S5). Herbivore load was low for both plant species $(0.41 \pm 0.04$ vs. $0.28 \pm 0.02)$. The rootmining weevil Diplapion stolidum (Germar) was the most abundant root herbivore on both plant species. Furthermore, we found larvae of the root-feeding weevil Cyphocleonus trisulcatus (Herbst) in southern France and larvae and pupae of the root-galling tephritid fly Oxyna nebulosa (Wiedemann) in the 

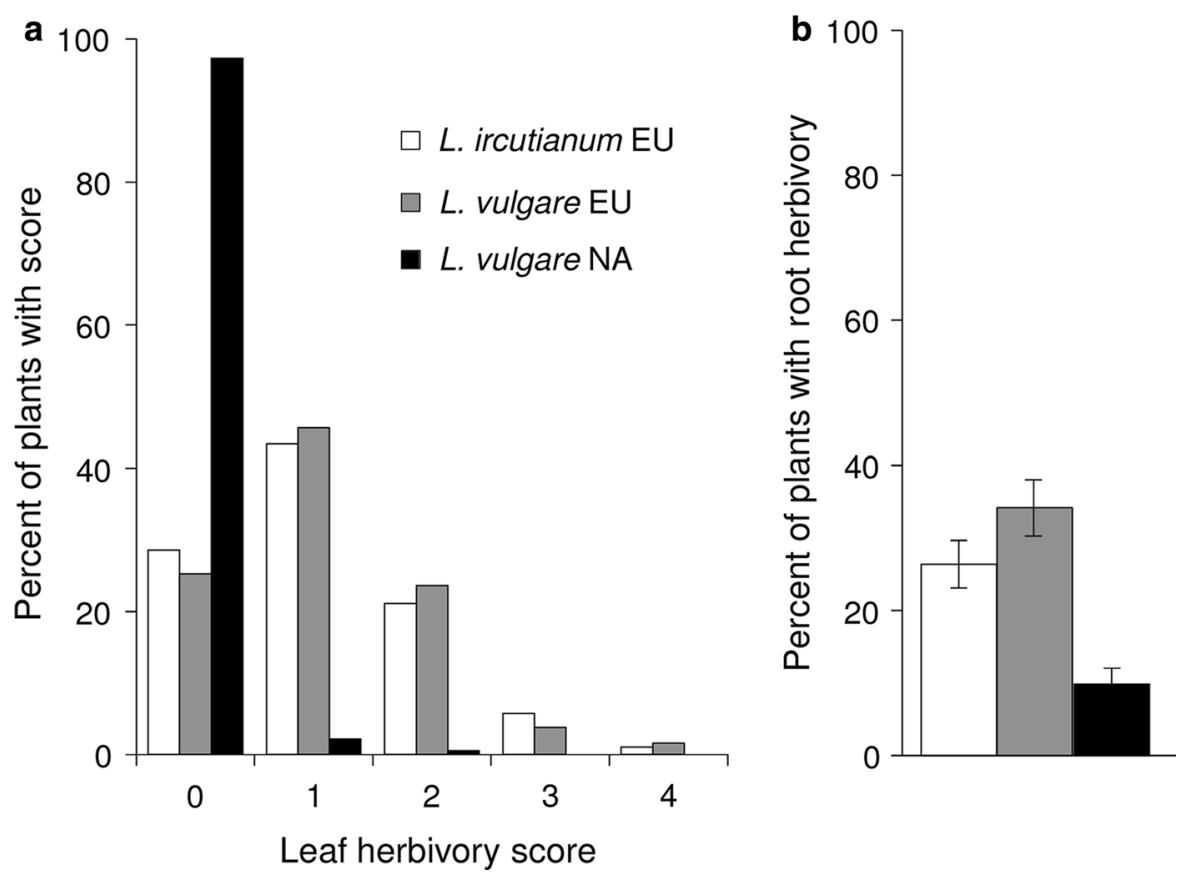

Fig. 2 a Leaf herbivory scores and $\mathbf{b}$ mean $( \pm$ SE) proportions of plants attacked by root herbivores for $L$. vulgare and $L$. ircutianum plants sampled in the native (Europe, EU) and invaded (North America, NA, only L. vulgare) range. $0=$ no damage; $1=$ minimal damage with no more than about $5 \%$ of any leaf damaged; $2=$ minimal damage plus some leaves with 5-10\% damage; $3=10-50 \%$ damage on multiple leaves, but fewer than half of all leaves affected; $4=$ at least half of all

Czech Republic. In addition, a few larvae of other herbivores such as Dichrorampha spp. and of the family Mordellidae were found in the roots of both plant species. The best-fitted models to explain the proportions of plants attacked by $D$. stolidum and $C$. trisulcatus both included Leucanthemum species and the number of shoots per plant as explanatory variables. Leucanthemum vulgare plants were more often attacked by D. stolidum and by $C$. trisulcatus than $L$. ircutianum $(z=-3.56, P<0.001$ and $z=-2.05, P=0.04$, Fig. 3a) and attack by both herbivores was positively associated with the number of shoots per plant $(z=3.44, P<0.001$ and $z=2.25$, $P=0.02)$ (Online Resource 3: Table S5). The bestfitted model for $O$. nebulosa included Leucanthemum species and vegetation height as explanatory variables. Leucanthemum vulgare plants were less often attacked by $O$. nebulosa than $L$. ircutianum ( $\mathrm{z}=2.22$, $P=0.03$, Fig. 3a) and attack by $O$. nebulosa was negatively correlated with vegetation height leaves with 10-50\% damage, and multiple leaves with more than $50 \%$ damage. In EU, the frequency distribution of leaf damage scores and the proportion of plants attacked by root herbivores were similar between $L$. vulgare and $L$. ircutianum $\left(\chi^{2}=0.9, P>0.05\right)$ but $L$. vulgare plants in NA had significantly lower leaf and root herbivory than those in EU $(P<0.001)$

(z $=-2.24, \quad P=0.03$ ) (Online Resource 3: Table S5).

In Europe, on average $3.5 \%$ of the Leucanthemum flower heads per population were attacked by Tephritis neesii Meigen and $3.8 \%$ by Microplontus campestris (Gyllenhal). Attack by these two herbivores was similar on L. vulgare and L. ircutianum (Fig. 3b). Seeds were frequently attacked by an unidentified gall midge [potentially Contarinia chrysanthemi (Kieffer)] but they were not included in the analyses because we were not able to reliably verify their presence or absence. In addition, $1.7 \%$ of the flower heads were attacked by Lepidopteran larvae [Dichrorampha acuminatana (Lienig \& Zeller) and others].

Comparison of L. vulgare between Europe and North America

Leucanthemum vulgare plants in the introduced range had significantly lower levels of damage by leaf 
Fig. 3 a Mean $( \pm$ SE) proportions of European $L$. vulgare and L. ircutianum plants per population attacked by the three most abundant root herbivores and $\mathbf{b}$ mean $( \pm \mathrm{SE})$ proportions of flower heads per population attacked by Microplontus campestris and T. neesii. * $P<0.05$; *** $P<0.001$, generalized linear mixed model with binomial error distribution
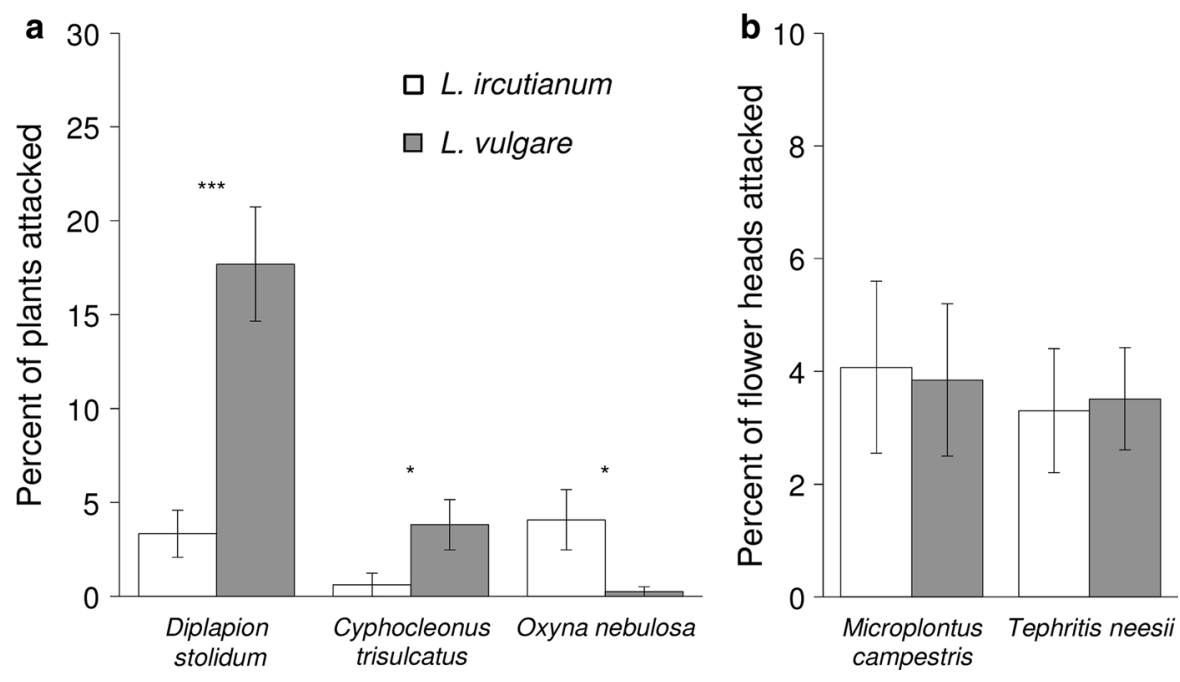

herbivores than $L$. vulgare plants in the native range $\left(\chi^{2}=109.3, P<0.001\right.$, Fig. 2a). In North America, only $3 \%$ of the plants were attacked by leaf herbivores while in Europe, $75 \%$ of the L. vulgare plants showed at least some attack. In the introduced range a lower proportion of $L$. vulgare plants were attacked by root herbivores than in the native range $(z=3.7$, $P<0.001$, Fig. 2b, Online Resource 3: Table S6) and no herbivores were found in any of the mined roots. None of the 4000 flower heads that were sampled from the $31 \mathrm{~L}$. vulgare populations in North America was attacked by herbivores.

\section{Discussion}

Our results from the ploidy screening of Leucanthemum populations in North America demonstrate that L. vulgare is by far more abundant in the introduced range than L. ircutianum. This is in accordance with surveys that had been conducted by Fernald (1903) and Mulligan (1958) in eastern North America where only a few populations of $L$. ircutianum were found. The higher invasion success of the diploid L. vulgare is in contrast to studies that found a positive association between polyploidy and invasiveness in plants (Lafuma et al. 2003; Kubátová et al. 2008; Schlaepfer et al. 2008; Treier et al. 2009; Pandit et al. 2011, 2014; te Beest et al. 2012). The higher abundance of $L$. vulgare in the introduced range could potentially be explained by differences in introduction pressure between the two species. However, both species largely overlap in their native range where $L$. ircutianum is more common than L. vulgare (Zelený 1982; Vogt 1991; Zelený 2004; Oberprieler et al. 2011). In addition, flow cytometric analyses which were conducted with 13 commercially sold seed sources purchased from twelve US and one Canadian seed companies revealed that only one of them was $L$. vulgare, all others were L. ircutianum (Stutz et al. unpublished data). Based on this, L. ircutianum had a higher chance to naturalize and spread in North America than L. vulgare.

\section{Comparison of European L. vulgare and}

\section{L. ircutianum}

In the native range, both Leucanthemum species were predominantly collected from grasslands and the vegetation height and cover, soil $\mathrm{pH}$ as well as plant species richness were similar in populations of both species. The two species are reported to have slightly different habitat preferences in their native range: $L$. vulgare is more abundant on dry calcareous grasslands and in more natural plant communities while $L$. ircutianum prefers nutrient-rich meadows and is more often found on disturbed sites and less specialised regarding ecological requirements and geological substrate (Zelený 1982; Hegi 1987; Vogt 1991; Oberprieler et al. 2011). In addition, L. vulgare is reported to be more thermophilous than L. ircutianum (Hegi 1987). Levin (1983) proposed that 
polyploidization leads to increased resistance to herbivores, because polyploids should have higher concentrations of secondary metabolites than diploids. We therefore hypothesized that in its native range $L$. vulgare would be more attacked by herbivores than $L$. ircutianum and that it would therefore be more likely to escape regulation by herbivores and become invasive in the introduced range. However, the similar herbivore attack rate and herbivore load between the two species do not support this hypothesis. Nevertheless, we found differences in the composition of the herbivore communities between the two Leucanthemum species. The two root-feeding weevils $D$. stolidum and $C$. trisulcatus were both more often found in L. vulgare than in L. ircutianum populations while the opposite pattern was found for the rootgalling tephritid fly $O$. nebulosa. Yet, in contrast to a generally larger plant size of polyploids (Ramsey and Ramsey 2014), the diploid L. vulgare produced more shoots and flower heads than the tetraploid $L$. ircutianum and our results suggest that the higher number of shoots of $L$. vulgare contributed to the higher attack rates of L. vulgare by D. stolidum and $C$. trisulcatus. Several field studies found differences in herbivore attack between closely related taxa differing in ploidy level (Thompson et al. 1997; Nuismer and Thompson 2001; Münzbergová 2006; Arvanitis et al. 2008; Halverson et al. 2008; Arvanitis et al. 2010; Richardson and Hanks 2011; Münzbergová et al. 2015). However, depending on plant taxa, herbivore species or even the population examined, polyploid taxa were either less, more or equally attacked by herbivores than the closely related diploids. For some taxa, differences in plant size or habitat preferences between cytotypes have been suggested to contribute to the differences in herbivory under field conditions (Münzbergová 2006; Arvanitis et al. 2007; Arvanitis et al. 2008; Richardson and Hanks 2011; König et al. 2014). For example, stem height has been suggested to be the main reason for the higher abundances of the leaf-galling fly Asteromyia carbonifera (Osten Sacken) and the aphid Uroleucon nigrotuberculatum (Olive) on hexaploid compared to sympatric diploid or tetraploid cytotypes of Solidago altissima L. in their natural habitat (Richardson and Hanks 2011). However, when grown in a common garden all cytotypes were similarly attacked by these herbivores, indicating that differences observed in the field were caused by habitat effects (Richardson and Hanks 2011). We cannot exclude that site characteristics not recorded in our study may also help explaining the higher, respectively lower, densities of $D$. stolidum, $C$. trisulcatus and $O$. nebulosa on $L$. vulgare, since sympatric populations of $L$. vulgare and L. ircutianum are rare and were not encountered during this survey.

\section{Comparison of L. vulgare in Europe and North America}

As hypothesized, L. vulgare plants in the introduced range were taller and had more flower heads and the population density was higher than in the native range. These findings are consistent with a general pattern emerging from literature reviews indicating that invasive plants perform better in their introduced compared to their native range (Hinz and Schwarzlaender 2004; Bossdorf et al. 2005; Parker et al. 2013). In our study, the populations surveyed in North America experienced higher mean and lower maximum temperatures than those in Europe, but differences in performance of $L$. vulgare between ranges remained significant even after we corrected for differences in these two climatic variables. A more benign climate does therefore not explain the better performance and higher density of $L$. vulgare in North America. Similarly, several other studies found better performance of invasive plants in their introduced compared to their native range and that these differences could not be explained by different environmental conditions between ranges (Jakobs et al. 2004; Ebeling et al. 2008; Hinz et al. 2012).

Vegetation height, vegetation cover as well as species richness of co-occurring species were higher in L. vulgare populations in Europe than in North America, suggesting that invasive $L$. vulgare populations experience reduced competition. Similarly, other biogeographic studies comparing performance of plant species native to temperate grasslands in Eurasia and invasive in the prairies in North America revealed that the average cover of the co-occurring vegetation is lower in the introduced than in the native range (Callaway et al. 2011; Alba and Hufbauer 2012; Hinz et al. 2012). In a neighbour removal experiment, Callaway et al. (2011) detected higher competitive effects of the surrounding vegetation on Centaurea stoebe L. growth and reproduction in its native European range compared to its invaded US range. Our results are in line with these findings, suggesting 
that reduced interspecific competition in the introduced range may contribute to the increased performance and density of $L$. vulgare. Further studies are needed to assess whether the significant negative correlation between vegetation cover and shoot density and number of flower heads per plant of $L$. vulgare populations in North America indicates negative impact of $L$. vulgare on co-occurring vegetation or suppression of $L$. vulgare by the co-occurring vegetation. The lack of a significant negative correlation between vegetation cover and $L$. vulgare performance in the native range is likely to be due to a considerably lower variation in vegetation cover compared to the invaded range (10 vs. $45 \%$ of the sites had a vegetation cover of more than $80 \%$ ).

Leaf- and root herbivory was significantly reduced and flower head herbivores were completely absent in the invaded range, as predicted by the enemy release hypothesis. Reduced herbivore attack in the invaded compared to the native range has also been found by several other biogeographical studies (Wolfe 2002; Bossdorf et al. 2005; Vilà et al. 2005; Ebeling et al. 2008; Adams et al. 2009; Cripps et al. 2010; Alba and Hufbauer 2012; Castells et al. 2013; Maurel et al. 2013; Blaisdell and Roy 2014; Cronin et al. 2015). One reason for the low herbivore attack in the invaded range might be that there are no congeneric species native to North America (USDA, NRCS 2015), which decreases the probability for native specialist insect herbivores to extend their host range to include $L$. vulgare as a new host plant. It has been reported that larvae of two native North American generalist tortricid moths [Argyrotaenia velutinana Walk. and Sparganothis sulfureana (Clem.)] feed on the inflorescences of $L$. vulgare in the vicinity of Ottawa (Guillet and Arnason 1995). In addition, a few European insects known to attack Leucanthemum species have accidentally been introduced to North America, including the monophagous Microplontus campestris reported from Ontario and Quebec (Anderson and Korotyaev 2004; Douglas et al. 2013) and at least three European Dichrorampha species feeding in the roots of Leucanthemum species have accidentally been introduced to North America [D. acuminatana, D. petiverella (L.) and D. sedatana (Busck) (Miller 1983; Dix et al. 1984; Roberts 1991; Roberts and Miller 2003]. However, all except $D$. sedatana are only reported from a restricted area in the eastern USA and none of these herbivores were found during our
North American surveys. Empty feeding tunnels observed in the roots of plants from the native and invaded ranges might have been caused by rootattacking larvae of Dichrorampha species or other herbivorous insects that left the roots for pupation prior to our surveys. In the native range, at least nine root-feeding Dichrorampha species are reported from Leucanthemum species (Razowski 2003) but only very few Dichrorampha larvae were found during our surveys. Most of the Dichrorampha species have one generation per year and adults fly from May to July. Larvae were therefore likely feeding in the leaves or shoots, which were not dissected, or too small to be detected during dissections.

Even though attack by herbivores was higher in the native range, most plants showed only minimal damage by leaf herbivores and only about one-third of plants was attacked by root herbivores and herbivore load was low. These results suggest that in the native range $L$. vulgare and $L$. ircutianum populations are not strongly regulated by herbivores. However, even if invasive plants are not regulated by natural enemies in their native range, they might still benefit from enemy escape in the introduced range. In the absence of enemies in the introduced range, plants may evolve to allocate fewer resources to defence, particularly defence against specialists, and more resources to growth or reproduction (Blossey and Nötzold 1995; Keane and Crawley 2002; MüllerSchärer et al. 2004; Broz et al. 2009, Hahn et al. 2012a). Studies are presently underway to identify whether the better performance of $L$. vulgare in the invaded compared to the native range is a plastic response or the result of post-introduction evolutionary changes.

While the overall herbivore load on $L$. vulgare in the native range was low, several root and flower head attacking herbivores were found during the surveys that are reported to be specialised on Leucanthemum species. Their suitability for biological control of $L$. vulgare in North America depends on their host specificity and how herbivore damage translates to plant fitness and whether the herbivores can reach high enough densities to reduce population densities of the target weed. Studies that assess the factors limiting the population growth rate of these biological control candidates in the native range may help predicting under which scenarios population outbreaks, a prerequisite for successful classical biological control 
(Gassmann 1996; Müller-Schärer and Schaffner 2008), can be expected for these herbivores.

\section{Conclusion}

In summary, our biogeographic survey revealed comparable herbivore loads on $L$. vulgare and $L$. ircutianum in the native range, suggesting that differential escape from specialist herbivores does not explain the higher invasion success of $L$. vulgare compared to $L$. ircutianum. When comparing $L$. vulgare between the native and the introduced range, plants in North America had significantly lower levels of herbivory, grew taller and produced more flower heads than plants in Europe, which is in line with the predictions of the enemy release hypothesis. Yet, the low levels of herbivory found in the native range suggest that the increased performance of $L$. vulgare in the introduced range is not primarily caused by enemy release and that other factors such as a shift in plant competition may play a more important role.

Acknowledgments We would like to thank the following people for collecting seeds and for assistance in locating field sites: J. Andreas, L. Baker, J. Birdsall, L. Blonski, L. BonaEggeman, M. Braun, J. Carder, C. Cassin, S. Cesselli, A. Cortilet, B. Drinkwater, L. Ely, M. Eylar, P. Folkard, A. Foster, J. Gaskin, S. Haight, H. Hanson, J. Hardin, M. Haverhals, P. Kotanen, K. Lee, M. Lepší, P. Lepší, J. Littlefield, K. Lucek, C. MacRae, K. Mann, A. Martinson, A. McClay, A. de Meij, V. Miller, A. Norton, C. Oberprieler, R. Pelant, J. Perz, V. Renevey, S. Reznik, V. Samková, M. Schwarzländer, S. Turner, R. Vogt, and P. Woods. We are grateful to A. Pena, M. Rutishauser, L. Sauvain and U. Studer for their help with field work, and to P. Mráz, A.-C. Cossy-Pasche, B. Šingliarová and V. Renevey for their help with flow cytometric analyses. We acknowledge the comments by two anonymous reviewers that helped improve this manuscript. This study was supported by the Ministry of Forests, Lands and Natural Resource Operations, British Columbia, the Canadian Agricultural Adaptation Program, through the Agriculture and Food Council of Alberta, the Montana Weed Trust Fund, through Montana State University, the Wyoming Biological Control Steering Committee, and the USDA Forest Service. KS $\breve{S}$ was funded by Grant No. P505/11/1112 of the Czech Science Foundation and long-term research development Project No. RVO 67985939 of the Czech Academy of Sciences.

\section{References}

Adams JM, Fang W, Callaway RM, Cipollini D, Newell E (2009) A cross-continental test of the enemy release hypothesis: leaf herbivory on Acer platanoides (L.) is three times lower in North America than in its native Europe. Biol Invasions 11:1005-1016

Alba C, Hufbauer R (2012) Exploring the potential for climatic factors, herbivory, and co-occurring vegetation to shape performance in native and introduced populations of Verbascum thapsus. Biol Invasions 14:2505-2518

Anderson RS, Korotyaev BA (2004) Some Palearctic weevils in the subfamily Ceutorhynchinae (Coleoptera, Curculionidae) recently discovered in North America. Can. Entomol. 136:233-239

Arvanitis L, Wiklund C, Ehrlén J (2007) Butterfly seed predation: effects of landscape characteristics, plant ploidy level and population structure. Oecologia 152:275-285

Arvanitis L, Wiklund C, Ehrlén J (2008) Plant ploidy level influences selection by butterfly seed predators. Oikos 117:1020-1025

Arvanitis L, Wiklund C, Münzbergová Z, Dahlgren Ehrlén J (2010) Novel antagonistic interactions associated with plant polyploidization influence trait selection and habitat preference. Ecol Lett 13:330-337

Bates D, Maechler M, Bolker B, Walker S (2014) lme4: linear mixed-effects models using Eigen and S4. R package version 1.1-7

Blaisdell GK, Roy BA (2014) Two tests of enemy release of commonly co-occurring bunchgrasses native in Europe and introduced in the United States. Biol Invasions 16:833-842

Blossey B, Nötzold R (1995) Evolution of increased competitive ability in invasive nonindigenous plants-a hypothesis. J Ecol 83:887-889

Bossdorf O, Auge H, Lafuma L, Rogers WE, Siemann E, Prati D (2005) Phenotypic and genetic differentiation between native and introduced plant populations. Oecologia 144:1-11

Broz AK, Manter DK, Bowman G, Müller-Schärer H, Vivanco JM (2009) Plant origin and ploidy influence gene expression and life cycle characteristics in an invasive weed. BMC Plant Biol 9:33

Callaway RM, Waller LP, Diaconu A, Pal R, Collins AR, Mueller-Schaerer H, Maron JL (2011) Escape from competition: neighbors reduce Centaurea stoebe performance at home but not away. Ecology 92:2208-2213

Castells E, Morante M, Blanco-Moreno JM, Sans FX, Vilatersana R, Blasco-Moreno A (2013) Reduced seed predation after invasion supports enemy release in a broad biogeographical survey. Oecologia 173:1397-1409

Clements DR, Cole DE, Darbyshire S, King J, McClay A (2004) The biology of Canadian weeds. 128. Leucanthemum vulgare Lam. Can J Plant Sci 84:343-363

Colautti RI, Ricciardi A, Grigorovich IA, MacIsaac HJ (2004) Is invasion success explained by the enemy release hypothesis? Ecol Lett 7:721-733

Comai L (2005) The advantages and disadvantages of being polyploid. Nat Rev Genet 6:836-846

Crawley MJ (1986) The population ecology of invaders. Philos Trans R Soc B 314:711-731

Cripps MG, Edwards GR, Bourdot GW, Saville DJ, Hinz HL, Fowler SV (2010) Enemy release does not increase performance of Cirsium arvense in New Zealand. Plant Ecol 209:123-134

Cronin JT, Bhattarai GP, Allen WJ, Meyerson LA (2015) Biogeography of a plant invasion: plant-herbivore interactions. Ecology 96:1115-1127 
DeWalt SJ, Denslow JS, Ickes K (2004) Natural-enemy release facilitates habitat expansion of the invasive tropical shrub Clidemia hirta. Ecology 85:471-483

Dhawan OP, Lavania UC (1996) Enhancing the productivity of secondary metabolites via induced polyploidy: a review. Euphytica 87:81-89

Dix ME, Tagestad AD, Stein JD, Jacobson M (1984) Detecting tip mining Olethreutinae (Tortricidae) moths in the northern and central Great Plains with synthetic attractants. USDA Forest Service Research Note 445. Rocky Mountain Forest and Range Experiment Station, Fort Collins

Douglas H, Bouchard P, Anderson RS, de Tonnancour P, Vigneault R, Webster RP (2013) New Curculionoidea (Coleoptera) records for Canada. Zookeys 309:13-48

Ebeling SK, Hensen I, Auge H (2008) The invasive shrub Buddleja davidii performs better in its introduced range. Divers Distrib 14:225-233

Erfmeier A, Bruelheide H (2004) Comparison of native and invasive Rhododendron ponticum populations: growth, reproduction and morphology under field conditions. Flora 199:120-133

Fernald ML (1903) Chrysanthemum leucanthemum and the American white weed. Rhodora 5:177-181

Gassmann A (1996) Classical biological control of weeds with insects: a case for emphasizing agent demography. In: Moran VC, Hoffmann JH (eds) International symposium on the biological control of weeds. University of Cape Town, Cape Town, pp 171-175

Greuter W (2006) Compositae (pro parte majore). In: Greuter W, Raab-Straube E von (eds): Compositae. Euro + Med Plantbase-the information resource for Euro-Mediterranean plant diversity. http://ww2.bgbm.org/EuroPlusMed. Accessed 7 May 2015

Guillet G, Arnason JT (1995) Some phytophagous insects found on Rudbeckia hirta and Chrysanthemum leucanthemum in the Ottawa/Hull area. Proc Entomol Soc Ont 126:95-97

Hahn MA, Buckley YM, Müller-Schärer H (2012a) Increased population growth rate in invasive polyploid Centaurea stoebe in a common garden. Ecol Lett 15:947-954

Hahn MA, van Kleunen M, Müller-Schärer H (2012b) Increased phenotypic plasticity to climate may have boosted the invasion success of polyploid Centaurea stoebe. PLoS One 7:e50284

Halverson K, Heard SB, Nason JD, Stireman JO (2008) Differential attack on diploid, tetraploid, and hexaploid Solidago altissima L. by five insect gallmakers. Oecologia 154:755-761

Heger T, Jeschke JM (2014) The enemy release hypothesis as a hierarchy of hypotheses. Oikos 123:741-750

Hegi G (1987) Compositae 2, Matricaria-Hieracium. In: Wagenitz G (ed) Illustrierte Flora von Mitteleuropa. Pteridophyta, Spermatophyta. Volume VI. Angiospermae, Dicotyledones 4, 3rd edn. Paul Parey, Berlin

Heywood VH (1976) Leucanthemum Mill. In: Tutin TG, Heywood VH, Burges NA, Valentine DH (eds) Flora Europaea 4. Cambridge Univ. Press, Cambridge, pp 174-177

Hierro JL, Maron JL, Callaway RM (2005) A biogeographical approach to plant invasions: the importance of studying exotics in their introduced and native range. J Ecol 93:5-15
Hinz HL, Schwarzlaender M (2004) Comparing invasive plants from their native and exotic range: what can we learn for biological control? Weed Technol 18:1533-1541

Hinz HL, Schwarzländer M, McKenney JL, Cripps MG, Harmon B, Price WJ (2012) Biogeographical comparison of the invasive Lepidium draba in its native, expanded and introduced ranges. Biol Invasions 14:1999-2016

Holm L, Pancho JV, Herberger JP, Plucknett DL (1979) A geographical atlas of world weeds. Wiley, New York

Jakobs G, Weber E, Edwards PJ (2004) Introduced plants of the invasive Solidago gigantea (Asteraceae) are larger and grow denser than conspecifics in the native range. Divers Distrib 10:11-19

Keane RM, Crawley MJ (2002) Exotic plant invasions and the enemy release hypothesis. Trends Ecol Evol 17:164-170

Khuroo AA, Malik AH, Reshi ZA, Dar GH (2010) From ornamental to detrimental: plant invasion of Leucanthemum vulgare Lam. (Ox-eye Daisy) in Kashmir valley, India. Curr Sci 98:600-602

König MAE, Wiklund C, Ehrlén J (2014) Context-dependent resistance against butterfly herbivory in a polyploid herb. Oecologia 174:1265-1272

Kubátová B, Trávníček P, Bastlová D, Čurn V, Jarolímová V, Suda J (2008) DNA ploidy-level variation in native and invasive populations of Lythrum salicaria at a large geographical scale. J Biogeogr 35:167-176

Lafuma L, Balkwill K, Imbert E et al (2003) Ploidy level and origin of the European invasive weed Senecio inaequidens (Asteraceae). Plant Syst Evol 243:59-72

Lavoie C, Saint-Louis A, Guay G, Groeneveld E, Villeneuve P (2012) Naturalization of exotic plant species in northeastern North America: trends and detection capacity. Divers Distrib 18:180-190

Levin DA (1983) Polyploidy and novelty in flowering plants. Am Nat 122:1-25

Lewis KC, Bazzaz FA, Liao Q, Orians CM (2006) Geographic patterns of herbivory and resource allocation to defense, growth, and reproduction in an invasive biennial, Alliaria petiolata. Oecologia 148:384-395

Liu H, Stiling P (2006) Testing the enemy release hypothesis: a review and meta-analysis. Biol Invasions 8:1535-1545

Loureiro J, Rodriguez E, Doležel J, Santos C (2007) Two new nuclear isolation buffers for plant DNA flow cytometry: a test with 37 species. Ann Bot 100:875-888

Maron JL, Vilà M (2001) When do herbivores affect plant invasion? Evidence for the natural enemies and biotic resistance hypotheses. Oikos 95:361-373

Maurel N, Fujiyoshi M, Muratet A, Porcher E, Motard E, Gargominy O, Machon N (2013) Biogeographic comparisons of herbivore attack, growth and impact of Japanese knotweed between Japan and France. J Ecol 101:118-127

McClay AS, Stutz S, Schaffner U (2013) Leucanthemum vulgare Lam., Oxeye Daisy (Asteraceae). In: Mason P, Gillespie DR (eds) Biological control programmes in Canada 2001-2012. CABI Publishing, Wallingford, pp 337-340

Miller WE (1983) New synonymies in nearctic Dichrorampha (Lepidoptera, Tortricidae). Proc Entomol Soc Wash 85:727-733 
Müller-Schärer H, Schaffner U (2008) Classical biological control: exploiting enemy escape to manage plant invasions. Biol Invasions 10:859-874

Müller-Schärer H, Schaffner U, Steinger T (2004) Evolution in invasive plants: implications for biological control. Trends Ecol Evol 19:417-422

Mulligan GA (1958) Chromosome races in the Chrysanthemum leucanthemum complex. Rhodora 60:122-125

Münzbergová Z (2006) Ploidy level interacts with population size and habitat conditions to determine the degree of herbivory damage in plant populations. Oikos 115:443-452

Münzbergová Z, Skuhrovec J, Maršík P (2015) Large differences in the composition of herbivore communities and seed damage in diploid and autotetraploid plant species. Biol J Linn Soc 115:270-287

Nuismer SL, Thompson JN (2001) Plant polyploidy and nonuniform effects on insect herbivores. Proc R Soc B 268:1937-1940

Oberprieler C, Eder C, Meister J, Vogt R (2011) AFLP fingerprinting suggests an allopolyploid origin of two members of the Leucanthemum vulgare aggregate (Compositae, Anthemideae) in central Europe. Nord J Bot 29:370-377

Olson BE, Wallander RT (1999) Oxeye daisy. In: Sheley RL, Petroff K (eds) Biology and management of noxious rangeland weeds. Oregon State University Press, Corvallis, pp 282-289

Pandit MK, Pocock MJO, Kunin WE (2011) Ploidy influences rarity and invasiveness in plants. J Ecol 99:1108-1115

Pandit MK, White SM, Pocock MJO (2014) The contrasting effects of genome size, chromosome number and ploidy level on plant invasiveness: a global analysis. New Phytol 203:697-703

Parker JD, Torchin ME, Hufbauer RA et al (2013) Do invasive species perform better in their new ranges? Ecology 94:985-994

Pinheiro J, Bates D, DebRoy S, Sarkar D, R Core Team (2014). nlme: linear and nonlinear mixed effects models. R package version 3.1-118

Prior KM, Powell THQ, Joseph AL, Hellmann JJ (2015) Insights from community ecology into the role of enemy release in causing invasion success: the importance of native enemy effects. Biol Invasions 17:1283-1297

R Core Team (2014) R: a language and environment for statistical computing. R Foundation for Statistical Computing, Vienna

Ramsey J, Ramsey TS (2014) Ecological studies of polyploidy in the 100 years following its discovery. Philos Trans R Soc B Biol Sci 369:20130352

Razowski J (2003) Tortricidae of Europe: Olethreutinae, vol 2. František Slamka, Bratislava

Richardson ML, Hanks LM (2011) Differences in spatial distribution, morphology, and communities of herbivorous insects among three cytotypes of Solidago altissima (Asteraceae) Am. J Bot 98:1595-1601

Roberts MA (1991) Two palearctic species of Dichrorampha discovered in Maine (Tortricidae). J Lepid Soc 45:169-171

Roberts MA, Miller W (2003) First report of the Palaearctic Dichrorampha acuminatana (Lienig \& Zeller) in North America (Tortricidae). J Lepid Soc 57:152-153

Roy BA, Coulson T, Blaser W, Policha T, Stewart JL, Blasdell GK, Güsewell S (2011) Population regulation by enemies of the grass Brachypodium sylvaticum: demography in native and invaded ranges. Ecology 92:665-675

Schlaepfer DR, Edwards PJ, Semple JC, Billeter R (2008) Cytogeography of Solidago gigantea (Asteraceae) and its invasive ploidy level. J Biogeogr 35:2119-2127

Soltis PS, Soltis DE (2000) The role of genetic and genomic attributes in the success of polyploids. Proc Natl Acad Sci USA 97:7051-7057

Stewart K, Bourn N, Thomas J (2001) An evaluation of three quick methods commonly used to assess sward height in ecology. J Appl Ecol 38:1148-1154

te Beest M, Le Roux JJ, Richardson DM, Brysting AK, Suda J, Kubešová M, Pyšek P (2012) The more the better? The role of polyploidy in facilitating plant invasions. Ann Bot 109:19-45

Thompson JN, Cunningham BM, Segraves KA, Althoff DM, Wagner D (1997) Plant polyploidy and insect/plant interactions. Am Nat 150:730-743

Treier UA, Broennimann O, Normand S, Guisan A, Schaffner U, Steinger T, Müller-Schärer H (2009) Shift in cytotype frequency and niche space in the invasive plant Centaurea maculosa. Ecology 90:1366-1377

USDA, NRCS (2015) The PLANTS database. National Plant Data Team, Greensboro. http://plants.usda.gov. Accessed 7 May 2015

Vilà M, Maron JL, Marco L (2005) Evidence for the enemy release hypothesis in Hypericum perforatum. Oecologia 142:474-479

Vogt R (1991) Die Gattung Leucanthemum Mill. (Compositae Anthemideae) auf der Iberischen Halbinsel. Ruizia 10:1-261

Williams JL, Auge H, Maron JL (2010) Testing hypotheses for exotic plant success: parallel experiments in the native and introduced ranges. Ecology 91:1355-1366

Wolfe LM (2002) Why alien invaders succeed: support for the escape-from-enemy hypothesis. Am Nat 160:705-711

Zelený V (1982) Kopretina bílá (Leucanthemum vulgare Lam. complex) v Československu. Academia, Prague

Zelený V (2004) Leucanthemum Mill. In: Slavík B, Štěpánková J (eds) Květena České republiky [Flora of the Czech Republic], vol 7. Academia, Prague, pp 236-242 